\title{
The Effect of Scientific Approach Against Naturalistic Intelligence Children 5-6 Years in Early Childhood
}

\author{
Kamtini $^{*}$, Isa Hidayati ${ }^{2}$, Husni Wardi Tanjung ${ }^{3}$, Siti Khadijah ${ }^{4}$ \\ ${ }^{1-4)}$ Universitas Negeri Medan. Indonesia \\ *kamtini@unimed.ac.id
}

\begin{abstract}
This study aims to determine the effect of a scientific approach to naturalistic intelligence of children age 5-6 years at PAUD. The type of research is quantitative research (experimental) using a posttest-only control design research. Data collection instruments was used observation. Based on data analysis, the average value in the experimental class is 12.5 and the control class is 9.2 , with a difference of 3.3 in the average value, so naturalistic intelligence at the age of 5-6 years in the experimental class and the control class obtains a difference significant. Based on the results of data analysis through the hypothesis test, obtained $t_{\text {count }}>t_{\text {table }}$ is $5.86>1.7074$ at $\alpha=0.05$ level. So, it can be concluded that using a scientific approach has a significant influence on children naturalistic intelligence.
\end{abstract}

Keywords: Scientific Approach, Naturalistic Intelligence, Early Childhood

\section{Introduction}

Children have various kinds of intelligence that exist in themselves, one of which is naturalistic intelligence. Naturalistic intelligence is the ability to categorize and create a hierarchy of the state of organisms such as plants, animals and nature [1]. Sie [2] also states that naturalistic intelligence includes the ability to enjoy her existence with nature so that she enjoys activities in nature, loves animals and plants. Maintaining nature and even being a part of nature itself is like visiting places that are inhabited by animals, and able to know the relationship between the environment and nature. This is a very high intelligence considering that not everyone can do it easily. Children who have high naturalistic intelligence have characteristics like to explore with nature, love animals, such as children who dare to hold directly animals, have a desire to nurture, dare to climb mountains. The core component of naturalistic intelligence is sensitivity to nature (flora, fauna, cloud formation, mountains) expertise in distinguishing members of each species, recognizing the existence of other species, mapping the relationships between several species both formally and informally Another naturalistic intelligence component is attention and a deep interest in nature, and carefulness in discovering the characteristics of species and other natural elements. Meanwhile, to develop intelligence Sujiono [3] naturalistic intelligence learning strategies that can be used are:

1) play in nature, discuss what is happening in the surrounding environment, 2) Look out the window, 3) Plants as decoration, use plants as naturalistic metamorphous to illustrate the concept of each lesson, bring pets to class, children are given the task note the animal's behavior, 4) Ecostudy, ecology integrated into every part of learning in school, the important conclusion is that children have an attitude of respect for the environment. 
Meanwhile factors affecting the naturalistic intelligence of children according to Jahja [4] include heredity, environmental factors consisting of nutrition, education. With the existence of several factors that affect children's intelligence both heredity / heredity and the environment. Both affect each other on children's intelligence. Every child is born with a different potential. As has been explained According to Gardner, in essence every child is a smart child, no child is born without intelligence [5]. One intelligence that needs to be developed is naturalist intelligence. So that there are several factors that influence, as educators and parents can help to optimize it. Children's intelligence will develop well if genetic and environmental factors support one another.

Based on observations made at PAUD Bunga Panda researchers found problems in children's naturalistic intelligence. Children do not explore the natural environment around, learning activities are only focused on the worksheet activities in children's textbooks, learning activities that are only in the room, learning activities that are afraid of making children dirty and wet, learning is carried out more dominantly to calistung activities, learning activities which is centered on the teacher by using the assignment method and less than the maximum use of the approach in learning activities.

So there are still children who have not been able to mention the types of plants, have not been able to grow crops simply, have not been able to protect the environment and plants. Children tend not to care about the environment, do not maintain environmental cleanliness and do not love animals around the child, this is seen where the child littering and there is no sense of care to maintain plants. The scientific approach allows early childhood to be able to build their own knowledge by searching for and discovering new knowledge from the impact of exploration carried out during learning activities. With scientific learning in learning activities carried out in Early Childhood Education will change the reality so far that learning that is carried out is only centered on the teacher (teacher center) will turn into child-centered learning activities. Where children who are required to be active in learning activities, children are given the opportunity to find their own knowledge by observing, asking questions, gathering information, reasoning, and communicating.

\section{Research Method}

This research is a quantitative research (experimental) by using a posttest-only control design research design. According to Sugiyono [6] quantitative research methods based on the philosophy of positivity are used to examine specific populations or samples. This type of research contained an experimental group and a control group randomly selected. Then the study population was all age groups 5-6 years totaling 40 people. The 5-6 years age group consists of two classes, namely classes B1 and B2, each class has 20 children.

The sample in this study were children aged 5-6 years in class B1 and B2, amounting to 40 people. Where class B1 has 20 children and in class B2 has 20 children. This sampling technique is to use random sampling, which is random sampling. Namely by inserting a roll of paper from each class (B1 and B2) into a bottle, then shaken and taken at random. Paper taken with the writing $\mathrm{X}$ as an experimental class and paper taken with writing $\mathrm{Y}$ as a control class. 
Table 1. Research Design

\begin{tabular}{lcc}
\hline Group & Treatment & Posttest \\
\hline Using Scientific Approach & $\mathrm{X}$ & $\mathrm{O}$ \\
Using the Assignment Method & $\mathrm{Y}$ & $\mathrm{O}$ \\
\hline
\end{tabular}

Information:

$\mathrm{O}=$ Final observation

$\mathrm{X}=$ learning using a scientific approach

$\mathrm{Y}=$ learning using the assignment method

Data collection techniques in this study used a non-test research instrument that is structured observation of naturalistic intelligence by looking at the characteristics of children's behavior. This research instrument uses observation guidelines:

Table 2. Observation Sheet Naturalistic Children's Intelligence

\begin{tabular}{|c|c|c|c|}
\hline Variable & Indicator & Description & Rating \\
\hline \multirow[t]{5}{*}{$\begin{array}{l}\text { Naturalistic } \\
\text { Intelligence }\end{array}$} & Love some pets & $\begin{array}{l}\text { 1. Children love pets by approaching them. } \\
\text { 2. Children pet and play with pets } \\
\text { 3. Children are able to tell stories about } \\
\text { pets. }\end{array}$ & \\
\hline & Take care of pets & $\begin{array}{l}\text { 1. Child is able to mention how to care for } \\
\text { pets } \\
\text { 2. The child is able to explain how to care } \\
\text { for pets (feeding, caring, and stroking) } \\
\text { 3. Children are able to practice how to care } \\
\text { for pets }\end{array}$ & \\
\hline & $\begin{array}{l}\text { Caring for plants } \\
\text { that are planted }\end{array}$ & $\begin{array}{l}\text { 1. The child knows the name of the plant } \\
\text { 2. Children can know how to plant plants } \\
\text { 3. Children are able to care for plants, for } \\
\text { example not picking haphazard leaves } \\
\text { and flowers and take good care of them } \\
\text { such as watering and fertilizing }\end{array}$ & \\
\hline & $\begin{array}{l}\text { Maintain } \\
\text { cleanliness of the } \\
\text { environment } \\
\text { proactively }\end{array}$ & $\begin{array}{l}\text { 1. Children throw garbage in its place } \\
\text { 2. The child understands that } \\
\text { environmental hygiene is very } \\
\text { important, such as looking at garbage by } \\
\text { taking it and throwing it in the trash } \\
\text { 3. Children are able to invite their friends } \\
\text { to dispose of trash in its place }\end{array}$ & \\
\hline & $\begin{array}{l}\text { Estimating the } \\
\text { natural condition of } \\
\text { the symptoms seen }\end{array}$ & $\begin{array}{l}\text { 1. The child is able to know the concept of } \\
\text { change in plants such as wilting flowers, } \\
\text { dry leaves if not watered } \\
\text { 2. Children are able to explain the concept } \\
\text { of change in plants such as wilting } \\
\text { flowers, dry leaves if not watered } \\
\text { 3. The child is able to overcome the } \\
\text { symptoms that are seen (such as } \\
\text { watering plants, and giving fertilizer) }\end{array}$ & \\
\hline
\end{tabular}

Source: children's naturalistic intelligence development guided by Yus Anita (2011: 82) 
Assessment criteria :

Value 3: if description 3 appears 3: very well

Value 2: if description 2 appears 2: good

Value 1: if description 1 that appears 1: enough

Value 0: if description 0 that appears 0: less

The data analysis technique used in this study was descriptive statistical techniques. Descriptive statistical techniques are used to describe the variable data development of naturalistic intelligence of children with steps 1) Stabulating data, 2) Calculating the average, 3 ) Interpreting the results of the average calculation. Based on the steps, before testing the research hypothesis, testing the requirements according to Standar Tingkat Pencapaian Perkembangan Anak (STPPA) in Table 3

Table 3. Interpretation of Children's Naturalistic Intelligence Development Data

\begin{tabular}{lc}
\hline Score & Child's Naturalistic Intelligence Development \\
\hline $0 \leq$ average score $\leq 0,75$ & Less \\
$0,76 \leq$ average score $\leq 1,50$ & Enough \\
$1,51 \leq$ average score $\leq 2,25$ & Well \\
$2,25 \leq$ average score $\leq 3,00$ & Very well \\
\hline
\end{tabular}

\section{Results and Discussion}

Data collection techniques in this study used observation techniques involving two classes that were given different treatments, the experimental class with the scientific approach and the control class using the assignment method [7]. The required observation sheet has been arranged so that it can be used to see the naturalistic intelligence of children aged 5-6 years.

a. Tabulation of observational data on naturalistic intelligence of children aged 5-6 years in the experimental class

The results of tabulating data in the experimental class using a scientific approach can be seen in the diagram below:

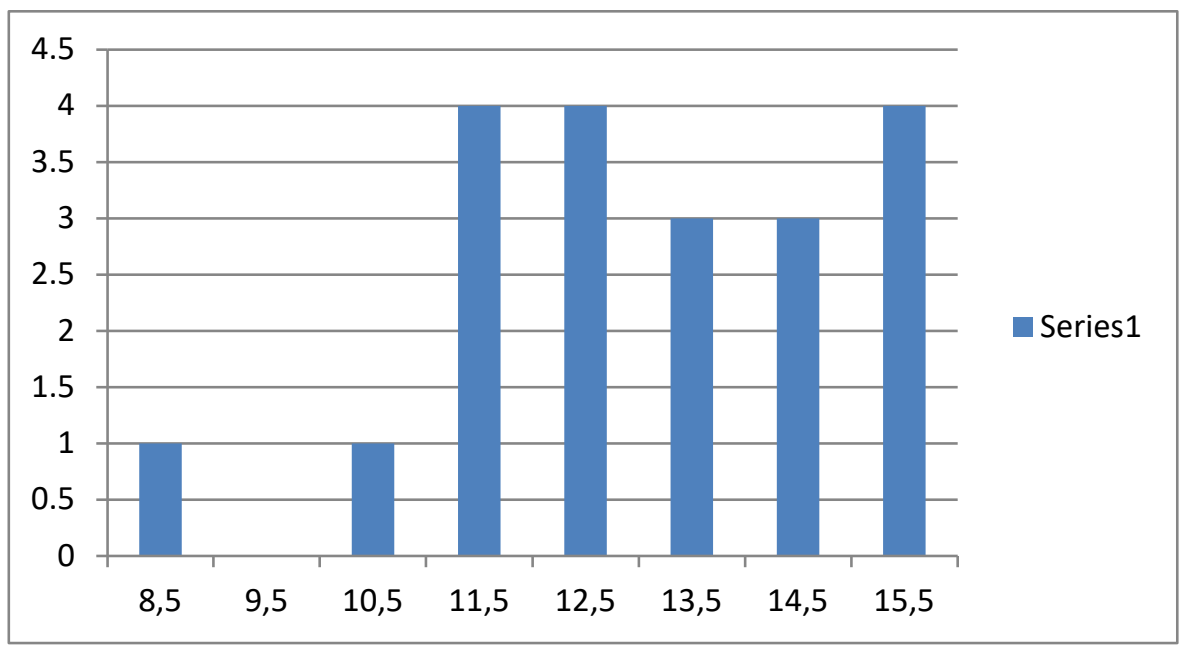

Figure 1.Observation Value Bar Chart in Experiment Classes 
In the bar chart above shows that the naturalistic intelligence of children aged 5-6 years in the experimental class obtained a value of 8.5 with a frequency of 1 , a value of 9.5 with a frequency of 0 , a value of 10.5 with a frequency of 1 , a value of 11.5 with a frequency of 4 , a value of 12,5 with a frequency of 4 , a value of 13.5 with a frequency of 3 , a value of 15.5 with a frequency of 4 , and the highest value at a value of 15.5, a value of 11.512 .5 and 15.5 at a more frequent frequency with a frequency 4.

\section{b. Tabulation of observational data on naturalistic intelligence of children aged 5-6 years in the control class}

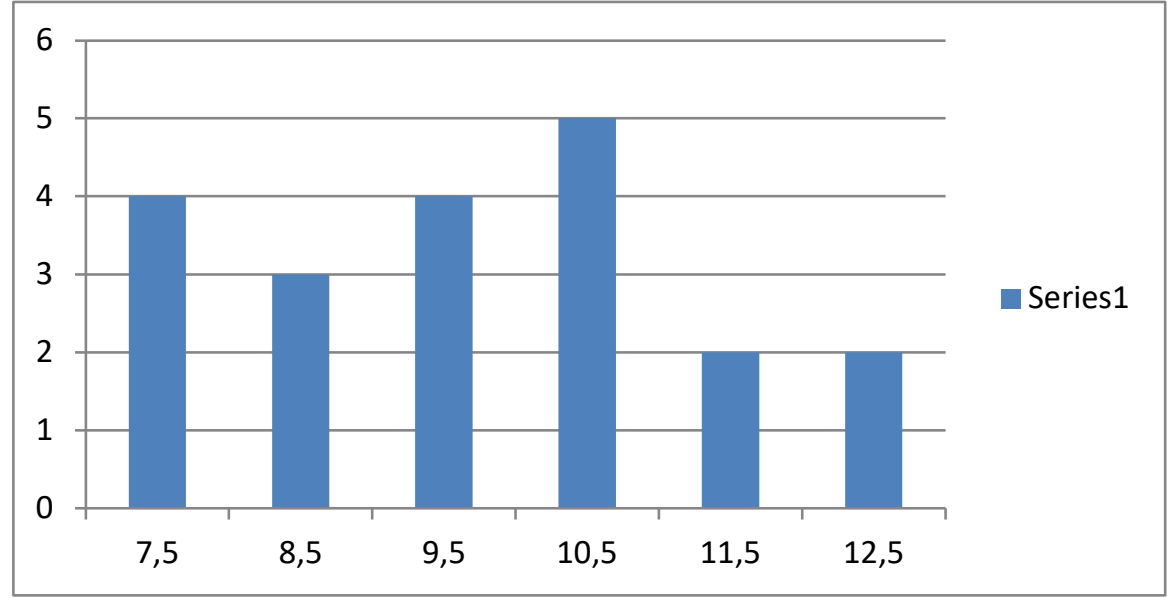

Figure 2. Observation Value Bar Chart in the Control Class

In the bar chart above shows that the naturalistic intelligence of children aged 5-6 years in the control class obtained a value of 7.5 with a frequency of 4 , a value of 8.5 with a frequency of 3 , a value of 9.5 with a frequency of 4 , a value of 10.5 with a frequency of 5 , a value of 11.5 with a frequency of 2 , a value of 12.5 with a frequency of 2 , and the highest value at a value of 10.5 with a frequency of 5 .

Based on the observation data from the experimental class and the control class above, it can be explained that the children in the experimental class have higher naturalistic intelligence compared to the naturalistic intelligence of the control class. This can be seen from the highest number of scores (15.5) and higher average scores (12.5) in the experimental class compared to the control class which has the highest number of scores (12.5) and average values $(9,1)$. In accordance with data analysis techniques to test the hypothesis of this study using the t-test, it is necessary to test the analysis requirements of normality and homogeneity.

Table 4. Summary of Test Results for Experiment Class Normaland Control Class (Normality test)

\begin{tabular}{cccccc}
\hline No & Data & Class & Lcount & Ltable & Conclusion \\
\hline 1 & Observation results & Experiment & 0,1026 & 0,190 & Normal \\
2 & Observation results & Control & 0,1336 & 0,190 & Normal \\
\hline
\end{tabular}


Based on the above table, obtained experimental class data $\mathrm{L}_{o}\left(\mathrm{~L}_{\text {count }}\right)=0,1026$ While $\mathrm{L}_{\text {table }}$ at the level $\alpha=0,05$, with $\mathrm{N}=20$ which is equal to 0.190 . Obtained $\mathrm{L}_{\text {count }}(0,1026)<\mathrm{L}_{\text {table }}$ $(0,190)$. The criteria are normally distributed data if $\mathrm{L}_{o}\left(\mathrm{~L}_{\text {count }}\right)<\mathrm{L}_{\text {table }}$ thus it can be concluded that the results of observations of naturalistic intelligence of children aged 5-6 years through the scientific approach are normally distributed.

The result of the normality test of the control class observation data obtained the value $\mathrm{L}_{o}$ $\left(\mathrm{L}_{\text {count }}\right)=0,1336$ while value of $\mathrm{L}_{\text {table }}$ at level $\alpha=0,05$, with $\mathrm{N}=20$ which is equal to0,190. Obtained $\mathrm{L}_{\text {count }}(0,1336)<\mathrm{L}_{\text {table }}(0,190)$. The criteria are normally distributed data if $\mathrm{L}_{\text {count }}$ $<\mathrm{L}_{\text {table }}$ thus it can be concluded that the results of observations of naturalistic intelligence of children aged 5-6 years through the assignment method are normally distributed.

Table 5. Summary of Homogeneity Tests (Homogeneity Test)

\begin{tabular}{cccccc}
\hline No & Class & Variance & $\mathbf{F}_{\text {count }}$ & $\mathbf{F}_{\text {table }}$ & Conclusion \\
\hline 1 & Experiment & 3,61 & 1,08 & 2,25 & Homogen \\
2 & Control & 3,34 & & & \\
\hline
\end{tabular}

From the homogeneity test calculation results obtained $F_{\text {count }}=1.08$ and $F_{\text {table }}$ values $(\alpha=$ 0.05 with $\mathrm{dk}$ the numerator and denominator 19 ) obtained 2.25 so that $\mathrm{F}_{\text {count }}<\mathrm{F}_{\text {table }}$ or 1.08 $<2.25$. The conclusion obtained from the results of the above calculation is the variance of naturalistic intelligence data of children aged 5-6 years both from the experimental class research and the control class coming from a homogeneous population.

\section{Hypothesis Testing}

After the data meets the requirements for normality and homogeneity. Then hypothesis testing is performed using t-test statistics on data obtained through observation of experimental and control classes. T-test results are obtained in the table below.

Table 6. Hypothesis Statement and Test

\begin{tabular}{cccccc}
\hline No & Class & Average value & $\mathbf{T}_{\text {count }}$ & $\mathbf{t}_{\text {table }}$ & Information \\
\hline 1 & Experimen & 12,5 & & & $\begin{array}{c}\text { There is a } \\
\text { significant } \\
\text { difference }\end{array}$ \\
\hline
\end{tabular}

Based on the table above, the value of $t_{\text {count }}$ is 5.86 and the value of $t_{\text {table }} 1,7074$ with (dk $=\mathrm{n} 1+\mathrm{n} 2)-2$ and the level $\alpha=0.05)$ The value of the $t_{\text {table }}$ with a level of $\alpha=0.05$ is obtained 1.7074 , so that it can concluded $t_{\text {count }}>t_{\text {table }}$ or $5.86>1.7074$. Thus the hypothesis $H_{o}$ is rejected and $\mathrm{H}_{\mathrm{a}}$ is accepted. Can be stated 'there is a significant influence of the scientific approach to naturalistic intelligence of children aged 5-6 years in PAUD Bunga Pandan, Lalang Village.

After being given a different treatment the naturalistic intelligence score of the children was obtained in the control class 9.2 while in the experimental class 12.5 . From the final observation results of the two samples obtained a difference of 3.3 from the data obtained there is a significant difference between naturalistic intelligence in the experimental class using the scientific approach and in the control class using the assignment method. The results of learning using a scientific approach are very good. This is because the influence of the scientific approach to learning activities provides direct experience for children by inviting 
children directly to engage in fun learning activities with real media or concrete learning activities. By involving objects that are real and real have a great impact on children in knowing and understanding, such as bringing pets directly, it will show how the child's reaction in knowing, treating these animals. Similar to the exploration activities of children invited out of the environment to observe, why it happened and what impact will be made a concrete example of seeing a pile of rubbish, why so what are the consequences, and see plants planted by children how the reaction of children when planting, children can know firsthand the type plants that are planted, from these activities the child will understand how to care for plants, know what the impact is if not treated. With these activities can provide an understanding of the material or activities that children do well, and with this activity can develop an attitude of awareness of children to love the environment by caring for and protecting the environment, plants and animals around the child.

This is in line with Erni Munastiwi's statement that Learning with a scientific approach can build creativity, imagination and ideas that can develop religious and moral, motor, cognitive, language, social emotional and artistic values. So that with the application of a scientific approach to learning activities that are designed with fun activities by implementing $5 \mathrm{M}$ activities, the child will be directly involved and active in learning activities especially in recognizing the environment around the child.

The results of applying the scientific approach to the experimental class turned out to be quite satisfying. It is known that naturalistic intelligence in the experimental class that is treated by utilizing the scientific approach has improved better than the control class that uses the assignment method. So based on the results of research that has been carried out in PAUD Bunga Pandan, Lalang Village, it can be concluded that the scientific approach has a positive influence on naturalistic childhood.

\section{Conclusion}

Based on the discussion that the researchers did, it can be concluded that naturalistic intelligence using a scientific approach has a significant effect on naturalistic intelligence of children aged 5-6 years compared to the assignment method. Suggestions in this research are shown to:

a. Teachers are expected to develop children's naturalistic intelligence by utilizing the implementation of a scientific approach because it provides concrete learning by using $5 \mathrm{M}$ activities (observing, asking questions, gathering information, reasoning and communicating).

b. For Headmaster as input to encourage teachers to take part in 2013 curriculum training on scientific approaches to develop concrete and fun learning.

c. For further researchers, it can be used as input and reference sources for conducting research related to the influence of a scientific approach to naturalistic intelligence of children aged 5-6 years.

\section{References}

[1] Yaumi Muhammad, I. N. (2013), Pembelajaran Berbasis kecerdasan Jamak (Multiple Imnelligences). Jakarta : Kencana.

[2] SIE, H. S. (2014), Aku Anak Cerdas. Jakarta: Elex Media Komputindo.

[3] Sujiono, Y. N. (2009), Konsep Dasar PAUD. Jakarta: Indeks. 
[4] Jahja, Y. (2011), Psikologi Perkembangan. Jakarta: Kencana.

[5] Yus, Anita. (2011), Model Pendiidikan Anak Usia Dini. Jakarta: Kencana.

[6] Sugiyono. (2016), Metode Penelitian Pendidikan. Bandung: Alfabeta.

[7] Daryanto. (2013), Pendekatan Pembelajaran Saintifik Kurikulum. Yogyakarta: Gava Media. 